\title{
Proposing local trees diversity for rehabilitation of degraded lowland areas surrounding springs
}

\author{
SOEJONO $^{1, \boldsymbol{\varphi}}$, SUGENG BUDIHARTA ${ }^{1}$, ENDANG ARISOESILANINGSIH ${ }^{2}$ \\ ${ }^{1}$ Purwodadi Botanic Garden, Indonesian Institute of Sciences, J1. Raya Surabaya-Malang, Km.65 Purwodadi, Pasuruan, East Java, Indonesia. \\ Tel./fax: +62-341-426046, `email: soejono59@gmail.com \\ ${ }^{2}$ Department of Biology, Faculty of Mathematics and Natural Sciences, Brawijaya University, Malang 65145, Indonesia
}

Manuscript received: 14 November 2012. Revision accepted: 24 March 2013.

\begin{abstract}
Soejono, Budiharta S, Arisoesilaningsih E. 2013. Proposing local trees diversity for rehabilitation of degraded lowland areas surrounding water spring. Biodiversitas 14: 37-42. This study was aimed to propose alternative trees diversity for rehabilitation of degraded lowland area surrounding spring. Data were collected by vegetation analysis of three sampling sites $\left(1^{\text {st }}\right.$. Cowek, $2^{\text {nd }}$ Gajahrejo, $3^{\text {rd }}$ Parerejo) to determine density, frequency, dominancy, diversity index and Important Value Index (IVI). The lists of plants in three sites were then compiled into an integrated list and used as reference for developing questionnaire. The questionnaire was then distributed to respondents who were chosen randomly. We recorded their preferences of tree species in rehabilitation program based on socio-economical and ecological aspects. Selected species were then proposed as alternative plants for rehabilitation of degraded spring area based on landscape topography and remaining vegetation coverage. The results showed that species diversity of Moraceae family was the highest than other families. In term of ecological aspect, Ficus racemosa, Artocarpus elasticus, Bambusa blumeana, Dendrocalamus asper, Gigantochloa atter, Ficus benjamina, Syzygium samarangense and Ficus virens showed high Important Value Index. On the other hand, based on socio-economic aspects, Ficus benjamina, Artocarpus elasticus, Artocarpus altilis, Artocarpus altilis "Seedless", Durio zibethinus, Ficus drupacea, Pangium edule, Ficus variegata, Michelia champaca, Aleurites moluccana and Ficus racemosa were the most preferred species by local community. Based on topography and vegetation coverage, spring surrounding areas were classified into four: steep and open, flat and open, steep and dense, and flat and dense. Therefore among of 120 species found in all sampling sites, there were respectively $63.3 \%, 95 \%, 25 \%$ and $44.16 \%$ species to be proposed and planted for rehabilitation in the four classified areas.
\end{abstract}

Key words: Tree diversity, rehabilitation, degraded areas, spring

\section{INTRODUCTION}

The impacts of habitat degradation are not only decreasing plant and animal species diversity, but also accelerating threatens ecological processes and natural resources in short and long term, including declining water quality and flow rate. It is known that water is an important product of ecosystem services to humans, and its quality and quantity depends on many factors; among them are the carrying capacity of physical environment and quality of vegetation coverage in the catchment area of spring. Therefore, conservation of plants diversity and ecosystems, both in situ, ex situ and rehabilitation of degraded areas is ecological significant value.

Various efforts to rehabilitate degraded lands and forests in Indonesia held using diverse ways or scenarios by the parties, but in general they often plant and prioritize exotic trees species, especially plant for timber production purposes, such as acacia (Acacia mangium), sengon (Albizia falcataria) and jabon (Anthocephalus cadamba) (Nawir et al. 2007). These plants will not grow long because it will be harvested to provide for wood needs, so the impact of rehabilitation for the urgent purposes such as sustainable environmental improvements and or ecological service is poorly integrated. In addition, not all rehabilitated sites are ecologically, socially and economically suitable to be planted using limited species richness as well as exotic ones, whereas, fault the plants choice for rehabilitation, will lead to counter-productive results. Some researchers showed that in the areas successfully reforested with pine, residents complained that the well water was shrinking (Sumarwoto 2003). Yonky et al. (2003) mentioned that pine has a high value of evaporation (1000-2500 mm year ${ }^{-1}$ ) depend on the location and climate condition. It will cause water deficit in the watershed, especially if it is planted in areas where rainfall is less than $2000 \mathrm{~mm}$ year $^{-1}$. However, in areas with high rainfall (3308 $\mathrm{mm} \mathrm{year}^{-1}$ ) as in Somagede, Sempor, Kebumen, where they studied, the pine forest is not cause of water shortages in the downstream. Controversy about this is still often discussed, because pine is an exotic and plant providing not only for reforestation, but also expected to support the success of business revenues, from wood and resin products (Yonky et al. 2003).

On the other hand, planting exotic plant, Acacia nilotica in Baluran, is expanding rapidly. This plant is then known to be invasive type (Hernowo 1999; Sabarno 2001; Iskandar 2006; Zuraida 2011), so its control becomes a significant 
problem. Djufri (2004) stated that the invasion of Acacia nilotica has resulted in the reduction of savanna in Baluran National Park reaching 50\%. Pressure to the savanna showed a great impact on the balance and preservation of whole ecosystem in Baluran. Therefore this study was aimed to propose plant diversity for rehabilitation degraded lowland area surrounding spring.

\section{MATERIALS AND METHODS}

This study was conducted in three sites in the subdistricts Purwodadi, Pasuruan, East Java (Figure 1). Information of spring locations was obtained from the local people. Data were collected in three sites $\left(1^{\text {st }}\right.$ Cowek, $2^{\text {nd }}$ Gajahrejo, $3^{\text {rd }}$ Parerejo) for vegetation analysis using Mueller-Dombois and Ellenberg's method as noted in (Soerianegara and Indrawan 1983) in order to determine density, frequency, dominancy, diversity index and Important Value Index. Eleven plots of 1ha square shape were observed for each site. The lists of plants in three sites were then compiled into one integrated list and used as reference for developing questionnaire. The questionnaires were then distributed to respondents chosen randomly in order to record data on local community preferences in selecting tree species, viewed from social and economic aspects. Selecting tree species to be proposed for rehabilitation degraded lowland areas surrounding water spring was conducted based on some criteria, such as (i) ecological (altitude requirement, pioneer-climax species, and fast or slow growing species, local or exotics), (ii) socio-economic aspects (wood or non wood products) and (iii) clustering degraded area by topography (flat or slope) and existing vegetation coverage (absence or presence of coverage). Based on topography and vegetation coverage, spring surrounding areas were classified into four: steep and open, flat and open, steep and dense, as well as flat and dense. Using these criteria, suitability of tree species was determined using a rapid assessment and expert judgment, based on field observations and records of empirical knowledge. This paper is an output of a thematic subprograms research activity of Purwodadi Botanical Gardens in 2011/2012, entitled, Study of vegetation and rehabilitation of habitats surrounding spring in Pasuruan district, East Java, Indonesia.

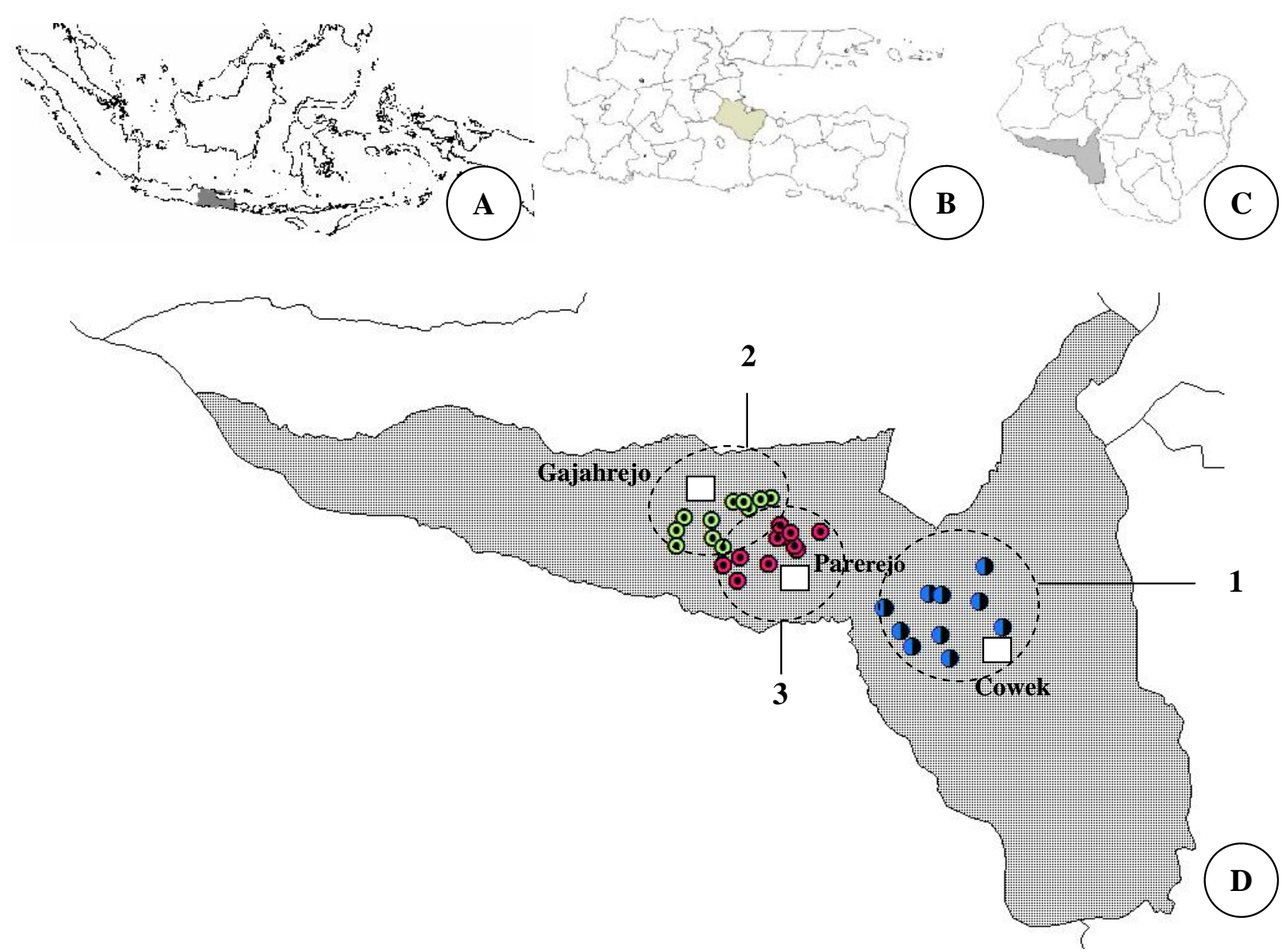

Figure 1. Research study sites: A. Indonesia, B. East Java province, C. Pasuruan district, D. Purwodadi subdistricts with three study sites, i.e.: 1. Cowek, 2. Gajahrejo and 3. Parerejo, each consists of 11 plots 
Table 1. Vegetation profile at three sampling sites around lowland spring in Districts Purwodadi, Pasuruan (Soejono and Budiharta 2011, modified)

\begin{tabular}{|c|c|c|c|c|}
\hline Variable & $1^{\text {st }}$ Cowek & $2^{\text {nd }}$ Gajahrejo & $3^{\text {rd }}$ Parerejo & All sites \\
\hline No. of families & 30 & 28 & 23 & 33 \\
\hline No. of genus & 55 & & 42 & 78 \\
\hline No. of species & 72 & 69 & 54 & 120 \\
\hline Dominant family & Moraceae & Moraceae & Moraceae & Moraceae \\
\hline Diversity index & 5.08 & 5.06 & 4.5 & - \\
\hline $\begin{array}{l}\text { Co-dominant species and } \\
\text { (\% IVI) }\end{array}$ & $\begin{array}{l}\text { Ficus racemosa }(29.4), \\
\text { Ceiba pentandra }(23.6), \\
\text { Artocarpus elasticus }(18.1), \\
\text { Swietenia macrophylla }(16.8), \\
\text { Ficus virens }(16.8) .\end{array}$ & $\begin{array}{l}\text { Bambusa blumeana }(53.9), \\
\text { Dendrocalamus asper }(41.2), \\
\text { Ceiba pentandra }(26.6), \\
\text { Gigantochloa atter }(15.4), \\
\text { Ficus benjamina }(5.3) .\end{array}$ & $\begin{array}{l}\text { Bambusa blumeana (91.4), } \\
\text { Syzygium samarangense } \\
\text { (25.7), Ceiba pentandra } \\
\text { (21.9), Ficus virens }(15.4), \\
\text { Dendrocalamus asper (12.9). }\end{array}$ & - \\
\hline Density (ind. ha ${ }^{-1}$ ) & 64 & 110 & 80 & 84.8 \\
\hline
\end{tabular}

\section{RESULTS AND DISCUSSION}

\section{Ecological aspects}

At least there were 120 species of trees growing in habitat around the lowland springs. It is known that the family Moraceae found as the highest species diversity than others, such as Ficus racemosa, also reached the highest importance value index in the first site Cowek, while Bambusa blumeana showed the highest importance value index in the second and third sites (Table 1). Trees species reached high Importance Value Index (IVI) including Ficus racemosa, Artocarpus elasticus, Bambusa blumeana, Dendrocalamus asper, Gigantochloa atter, Ficus benjamina, Ficus virens and Syzygium samarangense.

The average density of trees in the three sites were still relatively low, 64, 110 and 80 trees per ha. Lieberman and Lieberman (1994) reported the results of their research that the total number of stems $\geq 10 \mathrm{~cm} \mathrm{dbh}$, enumerated in 12.4 ha, a mean density is 446.0 individuals $\mathrm{ha}^{-1}$. This information is useful for determining tree density and species diversity existing in these sites, and then for estimating seedling density requirement for rehabilitation or restoration of degraded areas by considering their ecological and functional approach. According to Manan (1992), the best approach to restore diversity or for rehabilitation of degraded land was using the adjacent natural community structure (primary forests) as a vegetation model, especially in complexity, composition, vertical or horizontal stratification, richness, diversity and endemism rate. Consequently, the result of the succession acceleration by rehabilitation would be optimal as expected and harmony under natural conditions. In general, the more diverse plant species and structure, the better its effect on soil and water conservation.

\section{Socio-economic aspects}

Survey was carried out to record data on community preferences, involved 60 respondents from three sampling sites. In general, the results of survey showed that the species of Moraceae was a widely accepted by local communities for rehabilitation purpose of degraded areas around the spring. The high level of preference of respondents to the diverse species of Moraceae indicated that traditional knowledge on plant species commonly grown around the spring is still preserved and it is in harmony with the ecological aspects. Besides Moraceae, respondents preferred local tree species producing various economical benefits such as Durio zibethinus, Pangium edule, Parkia timoriana, Aleurites moluccana, Artocarpus altilis, Artocarpus elasticus as a producer of fruits or seeds, while Cananga odorata and Michelia champaca as a producer of aromatic flowers. Examples of selected plants for rehabilitation of open area around the spring and socioeconomic reason by local people are listed in Figure 2.

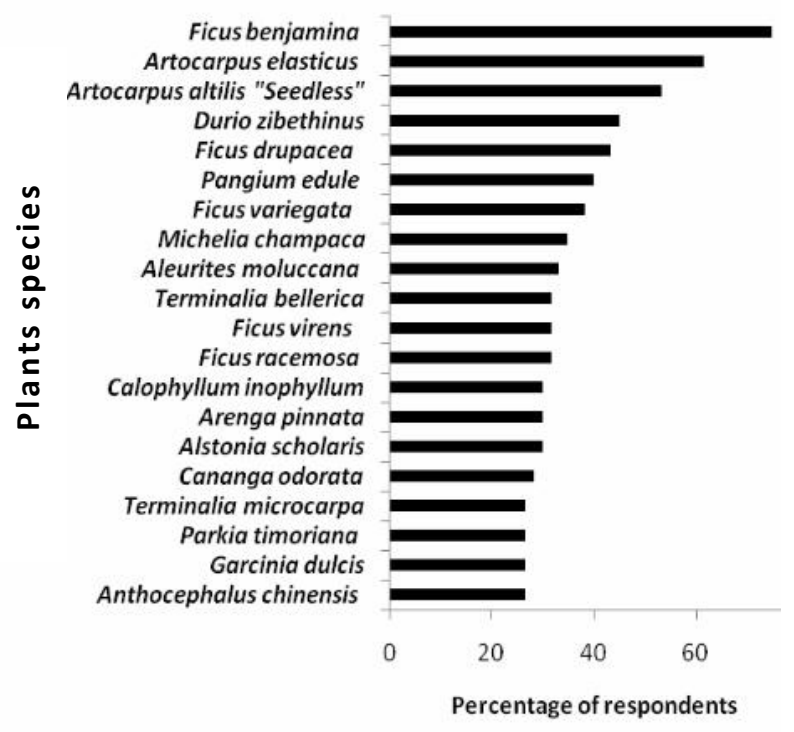

Figure 2. Some local tree species selected by local people for rehabilitation of open area around the spring and providing socioeconomic benefits

From Figure 2, it showed that diversity of tree species of the family Moraceae was higher than other families, consist of two genera and covering seven species (Artocarpus elasticus, A. altilis and Ficus benjamina, F. drupacea, $F$. variegata, $F$. virens and $F$. racemosa). Moraceae is a member of flowering plants, tribe Rosales. 
Using a simple technology, seed germination and seedling growth of Ficus benjamina, F. drupacea, F. racemosa, $F$. variegata and $F$. virens were successfully propagated by seeds (Soejono 2007). Main character of this genus was shown in the fruit namely figs. The fruit is formed from the base of the enlarged flowers and closed to form orbicular. The flowers are hidden inside the figs. The important thing to note that the most of Moraceae grown in lowland tropics, even, some species of the genus of Ficus, estimated that its distribution centered located in the Indo-Malay region, includes Indonesia. Some Ficus species are also known to be classified as a keystone species, because fruits are favored by wildlife as food. Therefore, these species show a great potential, if planted as a material for environmental remediation (Sastrapradja and Afriastini 1984; Berg and Corner 2005; Widyatmoko and Irawati 2007).

In accordance to the restoration and control of water resources, some species of Ficus show positive characteristics, such as, grow deep and broad rooting system, produce a dense branching in low position, develop a broad canopy, that are potential to reduce speed of rainfall drops. Thus destructive force to the surface layer of top soil is lower, and the water infiltration to the ground is better. As a result, water is retained relatively longer in the soil and released slowly, allowing the continuity of spring and reduce erosion or landslides (Soejono 2011). Yulistyarini and Sofiah (2011) stated that quality of various environmental services was depended on the density and diversity of vegetation, soil type and its management. They mentioned that, the high diversity of vegetation and thickness of litter will maintain hydrological function of recharge area and protect flow of water spring. Bruijnzeel 1990 mentioned that environmental carrying capacity in the water supply decreased, primarily due to changes in vegetation coverage, related to change in the pattern of evapotranspiration, infiltration rate, and the quality and quantity of surface flow. While Primack (1998) states that some important points in restoring degraded land community, mostly relies on community efforts to reestablish native plants, because this plant community usually produces most biomass and able to provide the structure for other community members. Robinson and Johnson (2006) state that appropriate plant materials for restoration by selecting species that are suitable for the site, grow from locally adapted sources, and have a solid genetic composition contribute to the success of project.

In line with this discussion, Bohnen and Galatowitsch (2005) stated that in most cases, high species diversity is recommended for restoration to increase ecological function. The first preference is typically for seed and plants that come from similar site conditions, and as close to the restoration site as possible. Edwards et al. (2010) introduced restoration model to support sustainable livelihoods - building both environmental and social resilience to climate change in the Shire Valley. They combined selected three multi-purpose species, Jatropha, neem and Moringa to spread risks and provide quick diverse benefits.
Potential tree species diversity for rehabilitation based on two criteria: topography and existing vegetation cover

Analysis of promising tree species based on topography and existing vegetation cover, implemented by a rapid assessment (judgment), field observations and records of empirical knowledge of the researcher team of Purwodadi Botanical Gardens, who often carry out field exploration in various remote tropical primary rain forest and also supported by main literature (Backer and Bakhuizen 1965 1968; Heyne 1987; Soerianegara and Lemmens 1994; Soejono 2011; Narko et al. 2012). Landscape around the spring was divided into four simple groups based on topography and existing vegetation: steep and open area (absence of trees coverage), flat and open, steep and dense (presence of dense trees), and flat and dense. Therefore among of 120 species found in all sampling sites, it was noted that: $63.3 \%, 95 \%, 25 \%$ and $44.16 \%$ respectively were proposed to be planted for rehabilitation in the four classified areas. Some examples of tree species proposed for rehabilitation in the mentioned classified areas, are listed in Table 2.

Table 2. Some examples of tree species showed a great potential for rehabilitation in the classified areas

\begin{tabular}{|c|c|c|c|c|}
\hline Species & 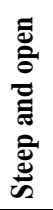 & 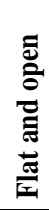 & 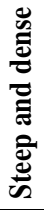 & 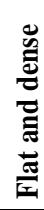 \\
\hline Adenanthera pavonina L. & & $\bullet$ & & $\bullet$ \\
\hline Aleurites moluccana (L.) Willd. & $\bullet$ & $\bullet$ & & $\bullet$ \\
\hline Arenga pinnata (Wurmb) Merr. & $\bullet$ & $\bullet$ & $\bullet$ & \\
\hline Artocarpus altilis (Park.) Fosberg & $\bullet$ & $\bullet$ & $\bullet$ & $\bullet$ \\
\hline Artocarpus elasticus Reinw.ex Blume. & $\bullet$ & $\bullet$ & $\bullet$ & $\bullet$ \\
\hline Artocarpus heterophyllus $\mathrm{Lkm}$. & $\bullet$ & $\bullet$ & & \\
\hline Baccaurea dulcis (Jack.) Mull. Arg. & & $\bullet$ & & \\
\hline Bambusa blumeana J.A. and J.H.Schultes & $\bullet$ & $\bullet$ & & \\
\hline Cananga odorata (Lmk) Hook.f.\& Thoms. & & $\bullet$ & & $\bullet$ \\
\hline Dendrocalamus asper (Schult.) Backer ex Heyne) & $\bullet$ & $\bullet$ & $\bullet$ & \\
\hline Dracontomelon dao (Blanco)Merr.\& Rolfe & $\bullet$ & $\bullet$ & $\bullet$ & $\bullet$ \\
\hline Dysoxylum gaudichaudianum ( A.Juss) Miq. & $\bullet$ & $\bullet$ & $\bullet$ & $\bullet$ \\
\hline Durio zibethinus Murr. & $\bullet$ & $\bullet$ & & \\
\hline Ficus benjamina L. & $\bullet$ & $\bullet$ & $\bullet$ & $\bullet$ \\
\hline Ficus callosa Willd. & $\bullet$ & $\bullet$ & & \\
\hline Ficus drupacea Thunb. & $\bullet$ & $\bullet$ & & \\
\hline Ficus hispida L. f. & & $\bullet$ & $\bullet$ & $\bullet$ \\
\hline Ficus variegata Blume & $\bullet$ & $\bullet$ & $\bullet$ & $\bullet$ \\
\hline Ficus kurzii King & $\bullet$ & $\bullet$ & $\bullet$ & $\bullet$ \\
\hline Ficus virens W. Aiton & $\bullet$ & $\bullet$ & $\bullet$ & $\bullet$ \\
\hline Ficus racemosa $\mathrm{L}$. & $\bullet$ & & $\bullet$ & \\
\hline Litsea glutinosa (Lour.) C.B. Rob. & $\bullet$ & $\bullet$ & $\bullet$ & $\bullet$ \\
\hline Gigantochloa apus (B1. Ex Schult.f.) Kurz & $\bullet$ & $\bullet$ & $\bullet$ & $\bullet$ \\
\hline Gigantochloa atter (Hassk.) Kurz ex Munro & & $\bullet$ & & $\bullet$ \\
\hline Microcos tomentosa J.E. Smith. & $\bullet$ & $\bullet$ & & \\
\hline Michelia champaca Linn. & $\bullet$ & $\bullet$ & $\bullet$ & $\bullet$ \\
\hline Protium javanicum Burm f. & $\bullet$ & $\bullet$ & $\bullet$ & \\
\hline Pangium edule Reinw. & $\bullet$ & & $\bullet$ & \\
\hline Parkia timoriana (DC.) Merr. & $\bullet$ & $\bullet$ & & \\
\hline Pterocymbium javanicum $\mathrm{R}$. Br. & & $\bullet$ & & \\
\hline Pterospermum javanicum Jungh. & $\bullet$ & $\bullet$ & & \\
\hline Sterculia foetida L. & $\bullet$ & $\bullet$ & & \\
\hline Syzygium pycnanthum Merr. and L.M. Perry & $\bullet$ & $\bullet$ & $\bullet$ & $\bullet$ \\
\hline Syzygium cumini (L.) Skeels & $\bullet$ & $\bullet$ & & \\
\hline Terminalia microcarpa Decne & $\bullet$ & $\bullet$ & & \\
\hline
\end{tabular}


Tree species selection mentioned above, should also consider ecological suitability in more detailed, including soil type, texture, structure and depth, climate, water use efficiency, as well as and autoecology of each species. Furthermore, the plant diversity for rehabilitation of degraded lowland areas surrounding spring was proposed by improving conventional replanting process using single species, and considering different perspectives, such as preserving plants diversity, prioritizing selection of local species, considering the ecological and socio-economic function, appreciating community preferences and adjusting to the local areas conditions. Hopefully, this proposes can technically implementable, ecologically sustainable, economically profitable, socially acceptable and can be developed in other places with similar conditions.

\section{Cooperation and commitment}

In fact the success of rehabilitation in degraded areas is not only determined by scientific considerations, but also determined by the result of mutual cooperation and commitment of all parties. To create synergies and optimize the collective efforts in biodiversity conservation management, Donald (2013) reported that management action needed to be enriched by research and allowed researchers to learn from practitioners. In the implementation of its activities, it is important to coordinate with relevant agencies, landowners and apply certain approaches or and dissemination to the public. Moreover, planted seedlings for rehabilitation are also required regularly protection and maintenance in early step until plants able to adapt to its environment.

\section{CONCLUSION}

It can be concluded that there were 120 species of local trees found in three sampling sites. Among them showed great potential as multipurpose plants and nominated by local people as material for rehabilitation of degraded lowland areas surrounding spring. Furthermore, this alternative plant diversity for rehabilitation may improve conventional replanting process using single species, and consider different perspectives, such as preserving plants diversity, prioritizing selection of local species, consider the ecological and socio-economic function, appreciate community preferences, adjust to the local areas conditions and finally establish cooperation with various parties. Hopefully, this propose can be developed in other places with similar conditions for optimal and sustainable ecological services of spring.

\section{REFERENCES}

Backer CA, Bakhuizen van den Brink Jr. RC. 1965. Flora of Java Vol. II. N.V.P. Noordhoff, Groningen, The Netherlands.

Backer C.A, RC. Bakhuizen van den Brink Jr. 1968. Flora of Java Vol. III. N.V.P. Noordhoff, Groningen, The Netherlands.

Berg CC, EJH Corner. 2005. Flora Malesiana Series I-Seed Plants Vol 17/ Part 2-2005, Moraceae (Ficus). National Herbarium Nederland, Leiden.
Bohnen JL, Galatowitsch SM. 2005. Spring peeper meadow: revegetation practices in a seasonal wetland restoration in Minnesota. Ecol Restor 23: $172-181$.

Bruijnzeel, LA. 1990. Hydrology of Moist Tropical Forests and Effects of Conversion: A State of Knowledge Review. UNESCO, Paris.

Djufri. 2004. Acacia nilotica (L.) Willd. ex Del. and problematical in Baluran National Park, East Java. Biodiversitas 5 (2): 96-104 [Indonesia]

Edwards K, Chimusoro J, Davidson G, Price K, Abbot P, Kayambazinthu D. 2010. Restoring degraded land in the Shire Valley, Malawi: lessons for community led initiatives that link restoration and the development of sustainable livelihoods. 18th Commonwealth Forestry Conference, Edinburgh. 28 June - 2 July 2010.

Yonky I, Rahardyan NA, Sukresno. 2003. The role of Hydrograph Analysis for Overcoming Water Conflicts in Society: A Case Study Sub Das Silengkong and Watujali BKPH (Section of the Forest Management Unit) Karanganyar, KPH (Forest Management Unit) South Kedu. Proceedings of the National Workshop Towards Ecosystem-Based Regional Resource Management to reduce the potential of inter-communal conflict. [Indonesia]

Hernowo JB. 1999. Habitat and local distribution of Javan Green Peafowl (Pavo muticus muticus Linneaus 1758) in Baluran National Park, East Java. Media Konservasi 6 (1): 15-22.

Heyne K. 1987. Useful plants of Indonesia (Translation). Forestry Research and Development Agency. Jakarta. [Indonesia]

Iskandar S. 2006. The efforts to against the forest invasive species in Indonesia; A review. Country Paper, Presented To The Workshop On Development Of A Strategy For The Asia-Pacific Forest Invasive Species Network. Dehradun, India, 16 April 2006.

Lieberman M, Lieberman D. 1994. Patterns of density and disperson of forest trees. La Silva: Ecology and Natural History of a Neotropical Rain Forest Part II Chap 8. hydro.csumb.edu/lieberman/docs/Density and dispersion chap $8 \mathrm{La}$ Selva book.pdf

Manan S. 1992. Silviculture. In: Kadri W (ed). Manual of Forestry. Indonesian Ministry of Forestry. Jakarta. [Indonesia]

McDonald T. 2013. Optimising our collective efforts-one step forward. Ecol Manag Rest 14 (1). DOI: 10.1111/emr.12032.

Narko D, Suprapto A, Lestarini W. 2012. An alphabetical list of plant species cultivated in the Purwodadi Botanic Garden. Purwodadi Botanic Garden, Indonesian Institute of Sciences. Pasuruan.

Nawir AA, Murniati, Rumboko L. 2007. Forest rehabilitation in Indonesia: Where to after more than three decades. Center for International Forestry Research (CIFOR). Bogor, Indonesia.

Primack RB. 1998. Conservation Biology. Yayasan Obor Indonesia. Jakarta. [Indonesia]

Robinson BW, Johnson R. 2006. Selecting native plant material for restoration projects. Extension Service, Oregon State University. OR.

Sabarno MY. 2001. Baluran savanna and its conservation efforts. Proceedings of the National Seminar on Biodiversity Conservation and Utilization of Dry Land Plant. Purwodadi Botanical Garden, Indonesian Institute of Sciences, Pasuruan [Indonesia]

Sastrapradja S, Afriastini JJ. 1984. Relatives of banyan. Series of Natural Resources 115. National Institute of Biology-LIPI. Bogor [Indonesia]

Soejono. 2007. Successful generative propagation of Golden Fig (Ficus bejamina L.) in Purwodadi Botanic Garden. Proceedings International Seminar Advances in Biological Science: Contribution Toward a Better Human Prosperity. Faculty of Biology, Gajah Mada University, Yogyakarta.

Soejono, Budiharta S. 2011. Ecological aspects and socio-economic preferences of local communities into species selection for water spring habitat rehabilitation: Case study in Purwodadi, Pasuruan. Proceeding International Conference on Biological Science Faculty of Biology Universitas Gadjah Mada 2011. ICBS BIO-UGM 2011).

Soejono. 2011. The trees species diversity around spring at two areas in Purwodadi, Pasuruan. Proceeding International Conference On Biological Science Faculty of Biology Universitas Gadjah Mada 2011 (ICBS BIO-UGM 2011).

Soemarwoto. 2003. Forests, afforestation/reforestation and water. Kompas, October 20, 2003. [Indonesia]

Soerianegara I, Indrawan A. 1983. Indonesian forest ecology. Department of Forest Management, Faculty of Forestry, Bogor Agricultural University. Bogor. [Indonesia]

Soerianegara I, Lemmens RHMJ. 1994. Timber Trees: Major Commersial Timbers Trees 5(1) Plant Resources of South-East Asia. Prosea Foundation, Bogor. 
Widyatmoko D, Irawati. 2007. Dictionary of terms conservation. Cente Plant Conservation Bogor Botanical Gardens. Indonesian Institute of Sciences, Bogor. [Indonesia]
Yulistyarini T, Sofiah S. 2011. Valuing quality of vegetation in recharge area of Seruk Spring, Pesanggrahan Valley, Batu City, East Java. Biodiversitas 12 (4): 229-234

Zuraida. 2011. Potency of Acacia nilotica as invasive species at Baluran National Park, East Java-Indonesia. Indian J Ecol 38: 216-217. 